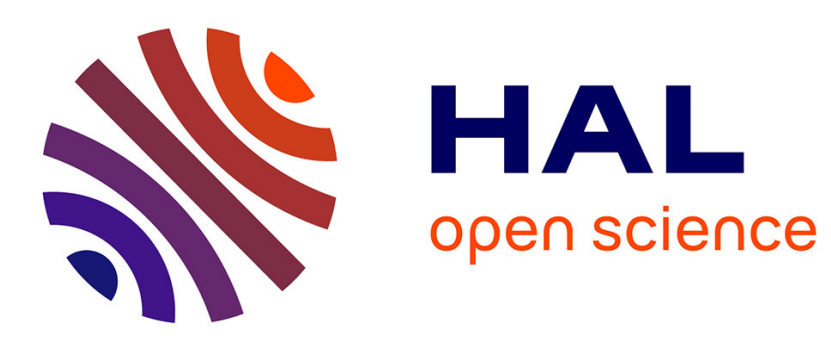

\title{
Datives and adpositions in North-Eastern Basque
}

Ricardo Rikardo, R. Etxepare, Bernard Beñat, B. Oyharçabal

\section{To cite this version:}

Ricardo Rikardo, R. Etxepare, Bernard Beñat, B. Oyharçabal. Datives and adpositions in NorthEastern Basque. 2011. artxibo-00605885

\section{HAL Id: artxibo-00605885 https://artxiker.ccsd.cnrs.fr/artxibo-00605885}

Submitted on 4 Jul 2011

HAL is a multi-disciplinary open access archive for the deposit and dissemination of scientific research documents, whether they are published or not. The documents may come from teaching and research institutions in France or abroad, or from public or private research centers.
L'archive ouverte pluridisciplinaire HAL, est destinée au dépôt et à la diffusion de documents scientifiques de niveau recherche, publiés ou non, émanant des établissements d'enseignement et de recherche français ou étrangers, des laboratoires publics ou privés. 


\author{
Datives and adpositions in North-Eastern Basque \\ Ricardo Etxepare (IKER) and Bernard Oyharçabal(IKER)
}

\title{
0. Introduction
}

Many languages show a degree of overlapping between the distinct categories of adpositions and oblique cases. The use of oblique cases very frequently extends to cover semantic roles that are typically expressed by adpositions. Spatial roles, such as locations, goals of motion or sources are a case in point. A common approach to this general phenomenon assimilates dative case-suffixes to adpositions, and specifies in the lexicon the relation between particular spatial roles and the two types of entities. In north-eastern varieties of Basque, datives can express spatial roles, such as targets of motion or locations. Basque is a particularly intriguing case of overlap, in the sense that its dative case-suffix behaves as a bona fide case marker outside the spatial cases, on the same level as absolutive and ergative cases, triggering agreement with the auxiliary and showing behaviour typical of DPs. We will argue that the spatial dative cases in north-eastern Basque are not different from what we see in canonical dative DPs: they are case suffixes, attached to nominal phrases, and expressing purely syntactic relations. The only difference being that the kind of functional support necessary to license case in verbal predicates can also be found internal to adpositional phrases, within certain conditions. Concretely, we will capitalize on recent work by Koopman (2000), Tortora (2009) and Den Dikken (2010) and argue that the spatial dative cases of north-eastern Basque are licensed in an aspectual projection internal to a phrase headed by a Path adposition. The argument will require a detailed discussion of some of the aspects involved in the syntax of postpositional phrases in Basque.

Crucial for the analysis of spatial datives here is the idea that lexically realized postpositions encode complex spatial properties, and that their semantic richness is a function of phrasal Spell Out, in the sense of Starke (2005, 2010): overtly realized adpositions in Basque lexicalize complex arrays of spatial features under conditions of adjacency. In the spirit of Koopman (2000) and much subsequent work, we take Place and Path adpositions to be able to project their own functional structure, in a way parallel to other lexical categories such as nouns or verbs. The lexical description for the insertion rule of overt adpositions, however, may prevent intermediate functional heads to project. Non overtly realized adpositions, on the other hand, only spell out a feature, and are insensitive to adjacency conditions. Functional projections in the complement domain of a silent adposition can project and attract embedded DPs to their Spec. The presence of spatial datives is related to the presence of an intermediate aspectual head in between the Path and the Place spatial features. From this point of view, the distribution of the spatial dative case in north-eastern dialects arises as the combined outcome of two interacting factors: the presence of a null Path adposition, available in north-eastern dialects, and lexicalization patterns common to all Basque varieties.

The discussion is based on data drawn from two different sources: a corpus of Navarrolabourdin writings of the second half of the XXth century ${ }^{1}$, and the answers of informants gathered in the developing database Basyque, which aims at building a syntactic database of the different dialectal varieties spread across the Basque domain. The Navarro-Labourdin variety is the largest subvariety of north-eastern Basque (the set of Basque varieties spoken in

\footnotetext{
${ }^{1}$ The written output of the authors examined expands from the early 50 s to the late $80 \mathrm{~s}$. The authors referenced in the corpus started to write before the advent of the normative pressure related to the expansion of standard Basque in the 70s, and showed little concern to accommodate to the standard norm.
} 
the French side of the Basque Country and bordering areas along the Pyrenees), and the one which is best represented in written form since the XIXth century. ${ }^{2}$

\section{Some general properties of dative case in Basque}

Dative is one of the so called grammatical cases in Basque. It shares this property with ergative and absolutive cases. Dative DPs agree with the auxiliary in number and person. The dative usually marks the recipient or beneficiary of the action:

$$
\begin{aligned}
& \text { a. Jonek Mikeli eskutitz bat bidali dio } \\
& \text { Jon-erg Mikel-dat letter one-abs sent aux[ditransitive] } \\
& \text { "Jon sent a letter to Mary" } \\
& \text { b. Jonek Mikeli autoa konpondu dio } \\
& \text { Jon-erg Mikel-dat car-the-abs fixed aux[ditransitive] } \\
& \text { "Jon fixed the car to Mikel" }
\end{aligned}
$$

Basque also employs dative marking for some non-participant roles in ditransitive constructions, such as ethical datives, datives of interest (2b) and possessor raising constructions (2a). Dative case also marks subjects of psychological predicates of the piacere class (2c) (Belletti and Rizzi, 1988):

$$
\begin{aligned}
& \text { a. Jonek Mikeli besoa hautsi dio } \\
& \text { Jon-erg Mikel-dat arm-D-abs broken aux[3sA-3sD-3sE] } \\
& \text { "Jon broke Mikel's arm" } \\
& \text { b. Esneak Mireni gaindi egin dio/*du } \\
& \text { milk Miren-dat over done aux[1sE-3sD-3sA]/[1sE-3sA] } \\
& \text { "The milk boiled over on Miren" } \\
& \text { c. Joni liburuak gustatzen zaizkio } \\
& \text { Jon-dat books-abs like-hab aux[3plA-3sD] } \\
& \text { "Jon likes books" }
\end{aligned}
$$

Dative case and agreement are not the only means by which Basque marks the presence of a dative argument. Finite sentences containing a dative argument require a particular affix (- $i-/-$ $k i$ - see Trask, 1995) in the inflected auxiliary. This affix has been variously called dative-flag (Rezac, 2006) or pre-dative affix (Hualde, 2003). The dative-flag precedes the agreement affix cross-referencing the dative argument. Take an unaccusative verb like nator "I come":

$$
\begin{aligned}
& \text { N-ator } \\
& \text { 1sA-root } \\
& \text { "I come" }
\end{aligned}
$$

The form in (3) can be extended to include reference to a dative argument, the end-point or beneficiary of the coming event. In that case, the agreement affix corresponding to the dative argument is preceded by the pre-dative affix (Hualde, 2003:207):

\footnotetext{
${ }^{2}$ See Lafitte (1944) and Arotçarena (1951) for two descriptive grammars.
} 


\author{
$\mathrm{N}$-ator-ki-zu \\ 1sA-root-predat-2sD \\ "I come to you"
}

In other words, the presence of a dative argument in a Basque finite sentence requires three things: (i) a dative case suffix; (ii) agreement in person and number; and (iii) an independent inflectional head which signals that the sentence has a dative.

It is generally admitted that dative arguments in Basque are case-marked DPs. Only DPs trigger agreement on the verb, and datives, as we saw, do. Only DPs enter into binding relations as antecedents, and this is the case with dative DPs too. Compare in this regard (5a), with a dative argument, and (5b), with a postpositional phrase:
a. Jonek Mireni $_{\mathrm{i}} \quad$ bere $_{\mathrm{i}}$ buruaz hitzegin dio
Jon-erg Miren-dat poss head talked aux[3sA-3sD-3sE]
"Jon talked to Miren about herself"
b. ${ }^{*} J_{\text {Jonek }}$ Mirenekin $_{\mathrm{i}}$ bere $_{\mathrm{i}}$ buruaz hitzegin zuen
Jon-erg Miren-with poss head-instr talked aux[3sA-3sE]
"Jon talked with Miren about herself"

As indirectly shown by the examples in (1-2), the dative argument typically precedes (and ccommands) the theme in Basque (see Fernandez, 1997 and Elordieta, 2001 for a thorough discussion).

\title{
2. North-Eastern varieties
}

The north-eastern varieties of Basque spoken in France present a series of contrasting properties in both the distribution of the case marker and its agreement properties. First, the semantic scope of the dative case suffix expands to include the marking of spatial functions of different sorts (section 2.1. and 2.2.), as well as the aspectual status of the event as unbounded (sections 2.3). ${ }^{3}$

\section{1. Spatial datives}

In north-eastern varieties, the dative marks the spatial goal of the event or situation:
a. Erretora badoa elizako atearen gakoari
Priest-D goes church-gen door-gen lock-dat
"The priest goes to the door-lock of the church"
b. Balkoin bat, bideari emaiten duena balcony one, road-dat give-hab aux[tr]-rel-D
"A balcony that looks onto the road"
(Etc. OM, 130)
c. Alemanen tankak oldartzen zirela Maginot harresiari (Lz, VII, 53)
German-gen tanks charge-ger aux-Comp Maginot fence-dat

\footnotetext{
${ }^{3}$ Those contrasting properties arise together in the XIXth century in the Navarro-Labourdin variety examined here. For the diachronic development of this phenomenon with particular reference to the Navarro-Labourdin subvariety, see Etxepare (to appear).
} 
"As the German tanks charged against the Maginot line"

d. Hurbiltzen da poliki-poliki bonetari approach-ger is slowly beret-dat

"He slowly approaches the beret"

Central and western varieties only admit spatial postpositions or complex postpositional phrases (see next subsection) in that case:

a. Erretora badoa elizako ate gakora

Priest-D goes church-gen door lock-all

"The priest goes to the door-lock"

b. Balkoin bat, bidera ematen duena

balcony one, road-all give-hab aux[tr]-rel-D

"A balcony that looks over the road"

d. Alemanen tankeak oldartzen zirela Maginot harresiaren kontra

German-gen tanks charge aux-Comp Maginot fence-gen against

"As the German tanks charged against the Maginot line"

e. Hurbiltzen da poliki-poliki txapelaren ingurura

draw-near aux slowly beret-gen vicinity-all

"He slowly approaches the beret"

Spatial datives do not agree with the auxiliary. (8) is an illustrative example:

*Balkoin bat bideari ematen diona

balcony one, road-dat give-hab aux[3erg-3dat-3abs]-rel-D

\subsection{Datives in complex postpositions}

There is a set of postpositions in Basque which encode directional paths. Some of those postpositions select DP grounds which are marked with a dative case suffix in the NavarroLabourdin variety:
a. Mendia-ri gora
Mountain-dat up
«Up the mountain »
b. Mendia-ri behera
mountain-dat down
d. Pareta-ri kontra wall-dat against
« Down the mountain »
« Against the wall»
e. Jujea-ri bisean-bis judge-dat vis-à-vis
« Vis-à-vis the judge »
f. Etxea-ri parrez-par
House-dat face-to-face
« Facing the house »
g. Har-i buruz
That-dat towards
« Towards him/her»

In those same contexts, the ground is marked by inessive postpositions or genitive cases in the rest of the Basque varieties: 

a. Mendia-n gora
b. Mendia-n behera
Mountain-in up mountain-in down
«Up the mountain »
« Down the mountain »
c. Pareta-ren kontra
d. Jujea-ren aurrez-aurre
wall-gen against judge-gen vis-à-vis
« Against the wall»
« In front of the judge »
e. Etxea-ren parrez-par house-gen face-instr-face
« In front of the house »
f. Har-en-gana
She-gen-ine-all
« Towards her/him»

\subsection{Datives in complements of aspectual verbs}

Aspectual verbs of the atelic sort select for dative nominalized clauses in Navarro-Labourdin (see section 3.1), as the progressive and inchoative aspectual verbs in (10): ${ }^{4}$
a. Eta horren ahultzeari
ari zirezte

and that-gen weaken-Nom-D-dat prog are

"And you are weakening that"
b. Josteari lotu da sew-nom-dat tied is
"He started sewing"

Dative aspectual complements do not agree either with the auxiliary, as shown in the examples.

\section{Spatial Datives and predicate classes}

The north-eastern spatial dative occurs across a variety of predicate types: motion verbs (4.1), stative verbs (4.2), oriented change of state verbs (4.3), verbs of comparison (4.4), and verbs of contact (4.5).

\subsection{Motion verbs and unbounded paths}

As a starting point in the examination of the conditions that allow the presence of a spatial dative in motion predicates, let us consider the verb itzuli. This verb has two related meanings in Basque: it means either « return, come back », or «turn towards something ». In its first reading, it takes an allative DP as the target of motion (12a). In its second meaning, it takes a dative DP as the target of an oriented path (12b):

$$
\text { a. Maiterenganat itzuli zen }
$$

\footnotetext{
${ }^{4}$ The dative also shows up in the object of a handful of unergative and semelfactive predicates (see Etxepare, to appear), for an aspect oriented analysis of the presence of the dative in those cases:
(i) a. Horr-i pentsatu
That-dat think
b. Atea-ri jo
door-dat knock
"To think about that"
"Knock on the door" 
Maite-gen-ine-all turned was

"He/she returned to (where) Maite (was)"

b. Itzuli zen Maiteri (Etchepare, 1958 :94)

Turned was Maite-dat

"He/she turned towards Maite"

Jackendoff (1990) provides the following conceptual schema for the "turn towards" meaning:

\section{Itzuli "Turn towards"}

[EVENT INCH ( [state ORIENT ([Thing Subject], [Path Object])])]

Compared to the basic conceptual function GO underlying the "return" reading of the verb, the conceptual representation of "turn towards" contains the basic conceptual function ORIENT, which does not imply motion into a goal. ORIENT has two arguments, one being the Figure of the relation, and the other one being a directional or unbounded Path, which in turn selects a spatial Ground. The above contrast suggests the following hypothesis: spatial datives occur with those predicates that do not represent a transfer of the Figure into the Goal. The turning motion leaves the Theme in a certain position vis-à-vis the spatial goal (Maite, in $12 \mathrm{~b}$ ), but does not take it into the spatial Goal. The latter spatial relation requires an overt adposition (12a).

Bihurtu in (14) is another verb that obeys a similar pattern. Bihurtu also has two different meanings: it means either "return" or "to turn against". The first meaning requires an allative goal, and entails that the theme has moved to a physical or abstract place. The second one does not give rise to such an entailment, it only means that the subject stands in a resisting or rebelling attitude vis-à-vis a certain goal:

a. Gaizkira bihurtu da

Evil-all turned-back is

« He returned to evil(-doing)»

b. Gaizkiari bihurtzen delarik

evil-dat turn-against-ger is-Comp-part

« As he turns against evil»

Abiatu "depart, to set in motion to a goal" can take an allative or a dative goal. The two cases do not have an identical meaning:

(15) a. Bidera abiatu da road-all moved is

"He moved to the road"

b. Bideari abiatu da road-dat moved is

"He/she set in his/her way" 
With the allative postposition, the predicate expresses a motion taking the theme to a physical space, the road. With the dative, it means that the subject has set in her/his way, with no further implication that a goal has been attained.

The verb erori provides a further example of the alternation between the dative and the allative. With an allative postposition erori means "fall" and the ground marks the physical space where the falling ends (16a). Our corpus also shows the variant in (16b), with a dative ground, where erori means "fall under" or "be inclined to/towards". In the latter case, no motion is entailed, and the ground is marked dative:

\section{a. Lurrera erori da} Floor-all fallen is

«He/she fell on the floor»

b. Jainkoaren nahi sainduari erortzen diren arima jenerosak

God-gen will holly-dat fall-hab aux-comp spirit generous-D-pl

« Those generous spirits who are inclined towards god's holly will »

Verbs like jarraiki/segitu "follow" or hurbildu "approach", which lexically entail that the theme has not reached the goal but are nevertheless goal-oriented require dative:

(17) a. Etsenplu oneri... jarraiki da bere... urhatsetan

Example good-dat follow is his steps-loc

"He follows the good examples in all his steps"

b. Hurbiltzen da polliki bonetari

approach-ger is slowly beret-dat

"He slowly approaches the beret"

If this is what underlies the use of dative ground DPs, we can make sense of the fact that verbs like arrive or come, which denote an attained spatial goal, are incompatible with the dative:
a. *Etxeari liburua heldu da
House-dat book-D arrived is
« The book arrived to the house »
b. *Etxeari eskale bat etorri da house-dat beggar one come is
« A beggar came home »

The data suggest the following partition in the set of Path exponents in Basque:

(19) a. Allative -> Bounded Path (Spatial Goal, TO)

b. Dative -> Unbounded Path (Oriented Path, TOWARDS)

\subsection{Stative Verbs}


The directional element associated to the dative suffix is particularly prominent when the predicate itself is such that it cannot contribute one. Stative verbs like $(20 a, b)$ are a case in point.

a. Balkoin bat,...bideari emaiten duena (Etc. OM, 130)

Balcony one road-dat give-hab aux(tr)-rel-D

"A balcony that looks onto the road"

b. Lehena salbu, oro Kaliforniako itsasoari dagoen lur zerrendan (G., 52)

first except all California-gen sea-dat is-rel land stretch-loc

"Except the first one, all of them in the stretch of land looking (lit. which is) onto California"

(20a) presents a complex predicate formed by the light verb eman "give" and a dative goal. The complex verb is a stative predicate that does not involve motion. The directional component is directly contributed by the dative ground. An even more clear case is (20b), where the copula egon "to be" physically locates the subject oro "all", but contributes nothing that could be interpreted as an orientation function. It is the presence of the dative ground that adds the directional component. Jackendoff (1983:173) proposes the following conceptual structure for cases like "to look onto":

\section{[STATE ORIENT ([Thing X], [Path y])]}

\subsection{Directed Change of State}

Consider the following cases:

$$
\begin{aligned}
& \text { a. Heien egitateeri begiak hetsi ditut } \\
& \text { Their deeds-dat eyes close aux(tr) } \\
& \text { "I closed the eyes to their deeds" } \\
& \text { b. Aphal dezagun burua jainkoaren nahi sainduari } \\
& \text { lower aux(tr) head-D god's will holly-dat } \\
& \text { "Let us bow to god's holly will" } \\
& \text { c. Haien erranari behar dugu nahitaez plegatu } \\
& \text { their words-dat must aux(tr) obligatorily yield } \\
& \text { "We must submit to what they say" }
\end{aligned}
$$

(Etc. FE, 179)

In all cases, the absolutive argument (the Figure) undergoes a change of state, and this change leaves it in a particular orientation vis-à-vis the Reference Point (someone else's deeds, god's will or someone else's words in (22)). But there is no movement that will take the figure into the Ground. I assume that a relevant part of the conceptual structure underlying those predicates involves the function ORIENT, as in the previous cases:

$$
\text { [Event CAUSE ([Thing...], [state ORIENT ( [Thing...], [Path ...]) }
$$

\subsection{Verbs of comparison}


Verbs of comparison are another class that show a dative suffix in the DP expressing the reference term of the comparison:

a. Hiru medaileri, hamabi nausi dituk three medals-dat twelve superior are

"Three modals win over twelve"

b. Hoik zure semeari preferatzen dituzu those your son-dat prefer-ger aux

"You prefer those to your son"

c. Lore hari zuen Lotik bere burua parekatzen flower that-dat Loti-erg himself level-hab

"Loti used to compare himself to that flower"

We will follow Broadwell (1996) in the idea that all verbs of comparison possess an abstract Path in their conceptual structure which ends in the term of comparison (see also Pasicki, 1988). In this case, however, the Path must be supplemented with reference to a set of vertical and horizontal axes that will determine whether the Figure is higher or lower than the reference term, or whether it is before or behind it. The latter cases can be assimilated to ordinary comparative relations. They also bear a dative reference term in north-eastern varieties:

(25) Suprefetari aintzinduz (Lz.,I,110)

subprefect-dat advancing

"Anticipating to the subprefect"

I will take verbs of comparison to need three conceptual components: a Figure (that which is compared), a Ground or Reference Term (the term to which it is being compared), and a set of axes that will determine their relative positions in the comparison relation, roughly, whether the latter holds in a horizontal (before, after) or vertical scale (higher, lower). The Figure is marked absolutive. The Ground is marked Dative.

$$
\text { [STATE } \mathrm{GO}_{\text {Comparison }}\left(\left[\text { Thing ....], [Path } \mathrm{TO} \text { [Place } \mathrm{AT}_{\text {axial relation }}[\text { Thing ...]])] }\right.\right.
$$

\subsection{Verbs of contact}

Dative DPs also surface as the support term for verbs expressing attachment:

a. Estekatzen dute kadiraren bizkarrari

(LZ. IV, 312) tie-ger aux armchair-gen back-dat

"They tie him to the back of the arm-chair"

d. Iragana josi nahi zuen zetorrenari

(LZ. VII, 128) past sew want aux come-Rel-D-dat

"He wanted to sew the past to the things that were coming"

c. ... Canal de Suez bi itsaso elgarri juntatzen dituen ur-bidea canal de Suez two seas each-other-dat unit-ger aux-Rel channel

"The Canal de Suez, a channel that unites two seas" 
According to Jackendoff (1990:106-116), verbs of attachment contribute a predication about a state, which contains a locative function AT. This locative function is enriched with the diacritic [+contact] which specifies that the figure and the reference term are in contact. For the inchoative case, Jackendoff proposes the following conceptual structure (1990:109):

[Event INCH $\left[\operatorname{state}\left(\left[\right.\right.\right.$ Thing...], [Place $\mathrm{AT}_{\text {contact }}[$ Thing...]])]

\subsection{Summary}

a. [EVENT INCH ( [ORIENT ([Thing...], [Path ...])])]

(oriented motion)

b. [EVENT CAUSE ([Thing...], [STATE ORIENT ( [Thing...], [Path ...]) (oriented change of state)

c. [EVEnt CAUSE [STATE GO ([Thing ...], [Path TO [Place $\mathrm{AT}_{\text {axial relation }}[$ Thing ....]]])])]) (comparison)

d. [EVEnt INCH [STAte $\mathrm{AT}_{\text {contact }}([$ Thing...], [Place $\left.\left.\ldots]].\right)\right]$

(verbs of joining)

e. [STATE ORIENT ([Thing ....], [Path ...])]

(stative verbs of orientation)

If we concentrate on the portions of the conceptual structure that directly represent the goal, we can further simplify (29) into (30):
a. [STATE ORIENT ( [Thing...], [Path ...])
b. [STAte GO [PLACE AT axial relation ([Thing...], [Place...]])])
c. [STATE $\mathrm{AT}_{\text {contact }}([$ Thing...], [Place ....]])]

The relation between the Figure and the Reference Term or Ground can be resumed in the following three cases: (i) the Figure is or becomes oriented to the dative Reference Term; (ii) the Figure is or ends up in a relative position vis-à-vis the Reference Term determined by a set of horizontal and vertical axes projected from the Reference Term; or (iii) the Figure is or ends up being in surface contact with the dative Reference Term. As shown by the stative function heading the locative relations, none of the conceptual structures entails actual motion.

\section{How does the dative arise?}

One obvious question regarding spatial datives is exactly how they compare to adpositions, or in other words, what regulates the alternative use of an adposition and a Case suffix in the expression of spatial relations. The conceptual analysis entertained in section 3 provides a potential answer: since the dative is associated to a well-defined set of spatial relations, the proper grammatical place to locate the alternation between adpositions and non-agreeing datives should be the lexicon. The idea can be spelled out as follows: if the spatial relation is one that denotes an orientation path towards a reference term, a contact situation between Figure and Ground, or a comparative relation, then the dative is the morphological exponent of the ground term in those cases. Allatives in turn will lexicalize the ground in other sorts of relations, and so will inessives. In this view, the Basque spatial lexicon would be arbitrarily divided between lexical exponents of category $\mathrm{P}$ and morphological cases, each of the categories encoding a subset of the (linguistically) available spatial relations. The dative suffix would be listed in the lexicon as encoding the following spatial semantic relations:

Dative Grounds $=\{$ Targets of unbounded directional paths, supporting entities in 
contact situations, reference terms in comparisons \}

This assimilates the non-agreeing, spatial dative suffix to the set of postpositions. In fact, some authors (see Albizu, 2001, for an elaboration of this idea) have directly identified the non-agreeing dative of eastern dialects to postpositional phrases. The fact that agreement is impossible with spatial dative goals would further add to the plausibility of this connection: postpositional phrases in Basque do not trigger agreement. The idea is in line with Asbury (2008), who takes oblique cases to lexicalize adpositional heads. In spite of its initial plausibility (somehow weakened by the heterogeneous nature of the spatial notions involved) we will try to show that the hypothesis that dative suffixes are postpositional heads directly encoding a spatial role in the cases at hand is misleading.

As we will see, dative grounds arise also in the domain of postpositional phrases, under the presence of overt postpositions that convey the kind of spatial notions covered by (31). The consequence of this observation is clear: if the spatial relations invoked in (31) are expressed by independent postpositions, then they cannot be directly encoded by the dative suffix. The argument requires a comparison of the three basic postpositional structures of Basque, that we develop in the following sections.

\subsection{Locational nouns and spatial suffixes}

The domain of spatial relations in Basque is expressed by means of three sets of grammatical formatives: (i) suffixes; (ii) locational nouns (De Rijk, 1990; Eguzkitza, 1997; Aurnague, 1996, 2001; Hualde, 2002); and (iii) non-inflected postpositions derived from locational nouns or adpositional sources (Aurnague, 2001; Hualde, 2002). The set of suffixes in Basque contains three basic forms: the inessive (32a), the allative (32b) and the ablative (32c). ${ }^{5}$
a. Etxea-n home-D-iness
b. Etxe-ra home-all
"In/at the house"
"to the house"
c. Etxe-tik home-abl
"from the house"

In addition to this limited set of spatial suffixes, Basque also has a rich inventory of locational nouns which allow a more flexible localisation of the figure and combine with the previous suffixes (see Euskaltzaindia, 1985; De Rijk, 1990; Eguzkitza, 1997; Hualde, 2002). An illustrative sample is provided below:

a. Etxe-a-ren aurre-a-n

House-D-gen front-D-loc

"In front of the house"

b. Zuhaitz-en arte-tik trees-gen among-from

"From among the trees"

c. Ohe-a-ren azpi-ra bed-D-gen under-all

"(to) under the bed"

\footnotetext{
${ }^{5}$ Plus other complex suffixes formed on the basis of the allative. See Hualde (2003).
} 


\section{d. Erreka-a-ren ondo-tik river-D-gen next-through \\ "Through the space next to the river" \\ e. Errekaren inguru-a-n \\ river-gen space-around-det-loc \\ "Around the river"}

According to De Rijk (1990), locational nouns behave as regular nouns: they require a complement with a genitive suffix, as binominal structures typically do, and bear suffixes that usually attach to nouns, such as the inessive postposition. This is illustrated in (34). Locational nouns participate in noun compounding (see De Rijk, 1990 and below), and many of them have a referential use and can be followed by a determiner, as shown in (35):

(34) Etxearen aurre-a-n

House-gen front-D-iness

"In front of the house"

\section{a. Etxearen aurrea/aitzina konpondu beharra dago}

House-gen front fix need is

"The front/façade of the house should be fixed"

b. Inguru hura arras hondatua zen area that completely ruined was

"That area was completely ruined"

c. Ondo hetan ibiltzen ginen place that-in walk-hab aux[1plA]

"We used to see that place quite often"

This referential use of locational nouns however, gives rise to some subtle shifts in meaning. It is clear that aurre/aitzin "front" identifies very different spatial entities in (36a) and (36b):

a. Etxearen aurre-a

House-gen front-D

"The façade/front-side of the house"

b. Etxearen aurre-a-n

house front-D-loc

"In front of the house"

"In the façade/front-side of the house"

Under the "referential" use in (36a), the only interpretation of the noun aurre is "façade" (that is, a part of the house). In (36b), its meaning is ambiguous between "space in front of the house" (thus not a part of the house itself) "and façade of the house". The ambiguity disappears if we force a syntactic structure that goes beyond a bare noun. For instance, adjectival modification is only possible under the "referential" interpretation:

(37) Etxearen aurre hondatuan house-gen front ruined-iness 
"In the ruined façade of the house"

"*In the ruined front of the house"

Adding a plural also forces a referential reading:

Etxearen aurreetan

house-gen façade-pl-iness

"In the façades of the house"

On the other hand, not all locational nouns admit a referential use. The non-referential interpretation is the only possible one for some of those nouns. This is the case for arte "space in between" as shown in (39): ${ }^{6}$

a. *Hango arteak meharregi ematen du that-gen space-in-between narrow-too looks aux[3sE-3sA]

"That space in between looks too narrow"

b. Besoen artean gorde du arms between kept aux[3sE-3sA]

"She kept it between her arms"

The only possible meaning for the noun arte is that of "space in between, projected from a ground or reference object embracing that space". Let us call this type of interpretation a "projective interpretation". Locational nouns thus define spatial regions projected from their DP complement (Aurnague, 1996). Projective interpretations are a characterizing feature of locational nouns when they are embedded in simple postpositional constructions. For Svenonius (2010), the syntactic differences between true nouns and locational nouns in their projective interpretation justifies defining the latter as a distinct functional item. Locational nouns with a projective meaning lexicalize a particular syntactic head, distinct from both the Ground (represented by the complement DP) and Place (represented by an adpositional head), that he calls Axial Part. The semantic content of the category can be described according to the following definition of axial parts by Jackendoff (1996:14): "The axial parts of an object its top, bottom, front, back, sides, and ends- ..., unlike standard parts such as handle or a leg, ...have no distinctive shape. Rather, they are regions of the object (or its boundary) determined by their relation to the object's axes. The up-down axis determines top and bottom, the front/back axis determines front and back, and a complex set of criteria distinguishing horizontal axes determines sides and ends." Axial Parts constitute a semantically distinct spatial notion and a syntactically autonomous functional category. Axial Parts are selected by a Place denoting adposition, and they in turn select a reference object or ground (40). This structure is uniform in the Basque area.

$$
\text { [PlaceP Place } \left.\left.{ }^{0} \text { [AxialP AxialP }{ }^{0} \text { [DPground } \mathrm{D}^{0} \mathrm{NP}\right]\right]
$$

In Basque the axial part is a bare noun, with no functional structure beyond its category feature itself. The nominal properties of the axial part head in this structure have a reflex in

\footnotetext{
${ }^{6}$ Under the spatial reading. Arte may also refer to a temporal interval, in which case it can be used as an independent noun, in eastern dialects:

(i) Arte hortan, finituko dugu

interim that-in finish-fut aux[1plE-3sA]

"In that interim, we'll finish it"
} 
Case assignment. ${ }^{7}$ The axial noun receives case from the adposition. The ground term either receives genitive case (41a) or forms a compound with the axial noun (41b):
a. Etxearen aurrean
house-gen front-Det-Loc
"In front of the house"
b. Etxe-aurrean
house front-D-Loc
"In front of the house"

The two options are syntactically represented as follows: ${ }^{8}$

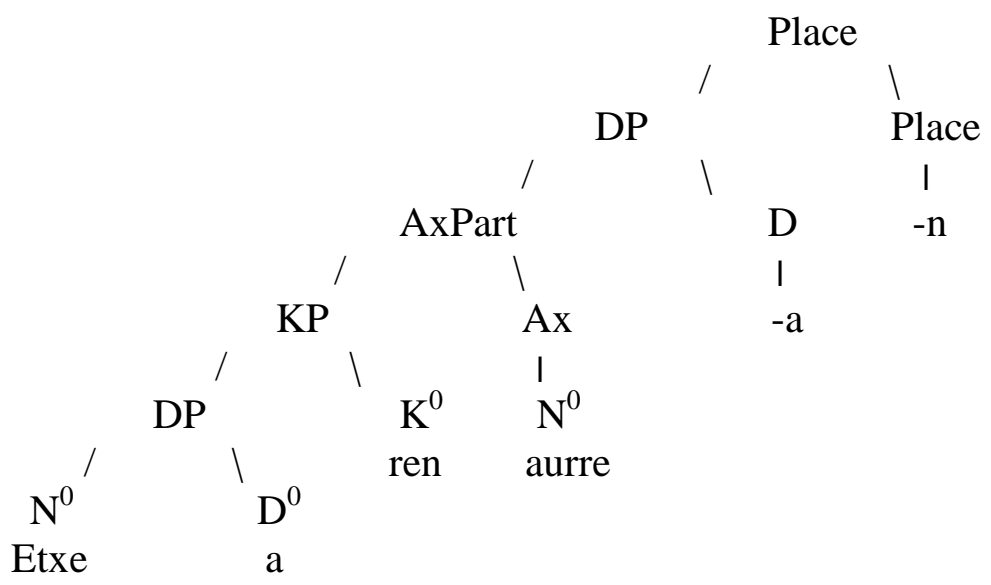

(43)

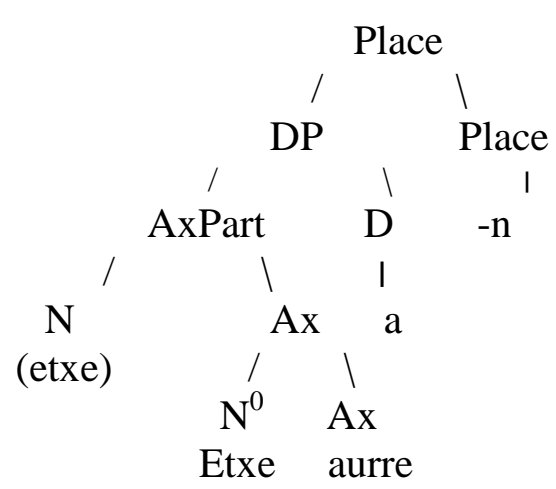

\subsection{Non-inflected postpositions}

Basque has another complex postpositional construction where the head of the construction is an invariant form expressing some abstract directional concept. The following is an illustrative sample: ${ }^{9}$

\footnotetext{
${ }^{7}$ Case seems to be assigned in Basque to both DPs and NPs, to judge from the ergative-absolutive case pattern of complex predicates with bare noun objects (see Laka, 1993).

${ }^{8}$ For the sake of exposition, I adopt a head-final representation for the adpositional phrases here. For the antisymmetry hypothesis as it applies to Basque, see Haddican, 2001, 2004, and the papers in Arteatx et alia (2008). See also footnote 7.

${ }^{9}$ For the directional component embedded in kontra "against", see Vandeloise, 1990.
} 
a. Etxearen kontra

House-D-gen against

"Against the house"

c. Aldapan behera

Slope-D-in down

"Down the slope"

e. Basoan zehar wood-D-in across

"Across the woods" b. Aldapan gora

Slope-D-in up

"Up the slope"

d. Basoan barna

Wood-D-in into

"Into the woods"

\section{f. Basoaz kanpo/landa}

Wood-D-instr out

"Out of the woods"

These invariant forms have different sources: some of them are borrowings from romance prepositions (Spanish contra "against") or nouns (Spanish campo; Gascon land/lande "open space"); most are derived from native locational nouns that have lost their autonomy as nouns, and mostly occur as a frozen part of the morphologically complex postposition. This is the case of gora "up", behera "down", barna "into", and zehar "across" in the sample ${ }^{10}$. Gora and behera also function independently as adverbs: ${ }^{11}$
a. Gora joan da upperside-all gone is
"He/she/it went up"
b. Behera joan da low-side-all gone is "He/she/it went up"

Morphologically, the adverbs behera and gora are composed by a locational noun, behe "lowside" or goi "upperside", plus a simple spatial suffix, the allative - $r a$ "to". The locational noun can be anaphorically referred to in the adverbial cases: ${ }^{12}$

(46) Gora/behera joan da, baina (behealde/goikalde hura) ikaragarri bustia zegoen up/down gone is but (low side/upperside that) terribly wet-D was "He/she went up/down, but that low area was terribly wet"

In its adverbial function, the complex postpositional phrase can also be questioned:
A: Nora joan da?
Where gone is
"Where is she/he gone?"
B: Gora/behera
Up/down

When the postposition is part of the complex directional postpositional phrase, on the other hand, anaphoric reference to it becomes impossible (48a), as well as questioning the invariant postposition (48b):
a. Mendian
behera joan da, \#baina (behealde hura) ikaragarri bustia zegoen

\footnotetext{
${ }^{10}$ Gora, behera and barna, are formed by the nouns goi, behe and barren, plus an allative suffix.

${ }^{11}$ Barna "through" cannot be used as an adverb. It is a phonologically shortened form of barren(er)a, which means not "through" but "to the interior of something". In barrena, the locational noun barren "inside" is easily identifiable, unlike in the shortened form. Barren(er)a can function as an adverb. Barna cannot.

${ }^{12}$ The parentheses are meant to indicate the possibility of pro-drop. Basque is a pro-drop language for the three arguments ergative, absolutive and dative.
} 
mountain-iness down gone is but (low-side) that terribly wet was "He/she went up/down the mountain, but that area was terribly wet"

b. *Mendian nora/nola joan da?

Mountain-iness where/how gone is

"How/which direction in the mountain he/she went?"

The fact that anaphoric reference to the locational noun is impossible and that questioning it by a wh-phrase is not possible either, suggests that the invariant postposition, unlike the adverb, does not possess an independent nominal part, but that the whole complex item is a head expressing direction. This difference between adverbial and non-adverbial complex postpositions is confirmed by the following fact: adverbial postpositional phrases admit noun compounding; non-adverbial ones don't. Thus, one can compound the locational noun behe or goi with another locational noun in the adverbial cases:

a. Behe-aldera joan gara

low-side-all gone we-are

"We went to the low-side"

b. Goi-aldean hotz zen

up-side-iness cold was

"It was cold in the high-side"

But noun compounding is impossible in the non-adverbial cases:

a. *Mendian behe-aldera joan gara

mountain-iness low-side-all gone we-are

"We went down to a low place in the mountain"

b. *Mendian goi-aldera joan gara

mountain-iness up-side-all gone we-are

"We went up to a high place in the mountain"

From the point of view of selection, invariant directional postpositions select spatial grounds which are themselves headed by a postposition, normally the inessive (44b, c, d, and e), and not genitive grounds (with the noticeable exception of kontra "against", but see section 7.1), as we would expect if they included a locational noun.

\subsection{Dialectal variation}

The ground terms of invariant directional postpositions are not uniformly realized in the Basque area: north-eastern dialects show a dative suffix where the central and western dialects have inessives and genitive. Our corpus presents the following cases: ${ }^{13}$
a. Paretari kontra
b. Patarrari behera
Wall-D-dat against slope-D-dat down
"Against the wall"
"Down the slope"

\footnotetext{
${ }^{13}$ (44f) is actually well attested in the central and western dialects too. The invariant postposition in this case is the stem-form of the verb begiratu "look at" that we translated as the gerundive "looking". The verb itself takes a dative object in both eastern and central dialects.
} 

c. Patarrari gora
d. Jujeari bisean-bis/parrez-par slope-D-dat up
"Up the slope" judge-dat face-to-face
"Face-to-face with the judge"
e. Etxeari buruz house-D-dat head-instr
f. Etxeari begira house-dat looking "Towards the house" "Looking at the house"

Interestingly, not all bare postpositions take a dative ground. Some of them, like kanpo, at, zehar or barna, in our corpus, take postpositional grounds, not dative ones:
a. Etxeaz/tik kanpo
b. Mendietan zehar
house-instr/abl outside mountains across
"Outside the house"
"Across the mountains"
c. Basoan barna
wood-in through
"Through the wood"
d. Etxetik at house-abl out
"Out of the house"

The bare postpositions that take dative grounds are easily identifiable in semantic terms: they are conceptually akin to the spatial relations that license dative goals in the verbal domain. They encode orientation (53), location vis-à-vis a set of axial vectors (54), and location plus surface contact (55).

a. Etxeari buruz/begira house towards/looking

"Towards the house"

$$
\begin{aligned}
& \text { a. Jujeari bisean-bis } \\
& \text { judge-dat face-to-face } \\
& \text { "Face-to-face to the judge" }
\end{aligned}
$$

a. [state ORIENT ( [Thing...], [Path ...])
a. Paretari kontra
c. $\left[\right.$ state $\mathrm{AT}_{\text {contact }}([$ Thing...], [Place $\left.\left.\ldots .]].\right)\right]$
wall-dat against
"Against the wall"

\subsection{Aspectual datives in the postpositional system}

To the set in (53)-(55) we must add the invariant postpositions gora "up" and behera "down". Those postpositions present the following intriguing properties: (i) they are only possible with motion predicates, as shown by the contrast in (56), and they are atelic, as shown by the fact that motion predicates supplemented with those invariant postpositions cannot be measured (57).

(56) a. *Etxea mendiari behera dago house-det mountain-dat down is

"The house is down the mountain"

b. Mendiari behera joan gara 
mountain-dat down go aux[1plA]

"We went down the mountain"

*Mendiari behera bortz minututan joan gara

mountain-dat down five minute-loc go aux[1plA]

"We went down the mountain in five minutes"

Gora and behera plus a dative ground, unlike their adverbial counterparts, are also incompatible with predicates that lexically entail the end of a Path, such as arribatu "arrive":

a. Mendira arribatu gara

mountain-all arrived we-are

"We got to the mountain"

b. *Mendiari behera arribatu gara

mountain-dat down-all arrived we-are

"We got down the mountain"

The aspectual restrictions related to gora and behera in their invariant postpositional form suggest that their meaning contribution occurs in a higher syntactic layer, one that is able to condition the aspectual interpretation of the higher predicate. We will elaborate on this idea in section 7.2.

\subsection{On the contribution of the dative}

Let us now have a second look at the postpositional contructions showing a dative ground, represented in (59):
a. Etxeari buruz house towards
b. [STATE ORIENT ( [Thing...], [Path ...])
"Towards the house"

(59) constitutes a powerful argument against a lexical approach to spatial datives as sketched in the beginning of the section. In the contexts above, the directional spatial component is overtly lexicalized by the invariant postposition. To the extent this is true, the dative cannot directly encode the Path function involved in those cases. In other words, although the dative is somehow associated to the Path conceptual function, it does not directly express it. In the context of verbal predicates, we will assume the underlying presence of a tacit Path head ccommanding the dative-marked ground in some local domain (60b). This silent Path head is the tacit equivalent of the invariant postpositions lexicalizing the Path head in the adpositional domain (60a).
a. [PathP [KP etxea-ri] buruz etxeari
b. [vP V...[PPath $\mathrm{P}^{0} \ldots[$ Ground DP]]]

The tacit Path adposition is manifest in those cases where the predicate does not contain a Path denoting component, as in the purely stative predicate egon "(locative) be":

$$
\text { a. Itsasoari dago }
$$


sea-dat it-is

"It is facing the seaside"

b....BE $\left[\emptyset_{\text {PATH }}\left[\right.\right.$ the sea $\left.\left.{ }_{\text {DAT }}\right] \ldots\right]$

\section{Topological conditions on spatial suffixes}

If (61) underlies what we called spatial datives, we must wonder about the following: assuming that $\mathrm{P}$ in a structure like (61) instantiates an orientation path, why is (62) impossible?

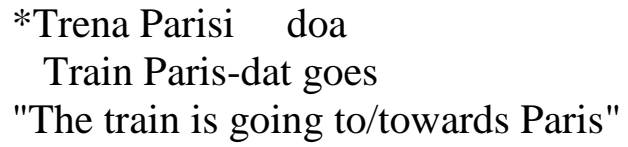

There is in principle nothing wrong with (62): if the relevant adposition is one that expresses an orientation path, and orientation paths license the dative in postpositional phrases, then we would expect (62) to be possible. We think that (62) actually provides an important clue to the conditions under which the dative is licensed. The proper way to express (62) includes an allative:

(63) Trena Pariserat (buruz) doa

Train Paris-all (towards) goes

"The train is going to/towards Paris"

There is an important difference between lexical postpositions and the purported abstract, unrealized one. Aurnague (2001) notes that the allative imposes certain topological restrictions in the relations between the Ground and the Figure. He notes for instance, that the Ground selected by an allative postposition must be such as to be able to include or to serve as a support for the Figure. A clause like (64) is odd because no such relation can be envisioned (Aurnague, 2001:197):

$$
\begin{aligned}
& \text { ??Ganibetara joan da } \\
& \text { knife-all gone is } \\
& \text { "He/she went to the knife" }
\end{aligned}
$$

We note here that the few cases where the eastern dative occurs in the place of the allative are cases where such a relation cannot be established. Compare in this regard $(65 a, b)$ and $(66 a, b)$ :

(65) a. Erretora joan da atearen gakoari priest gone is door-gen lock-dat

"The priest went to the door-lock"

b. ??Erretora joan da atearen gakora priest gone is door-gen lock-all

"The priest went to the door-lock"

(66) a. Beharri guziak solas berri bati zoazin ear all-D conversation new one-dat went "All ears went to a new conversation" 


\section{b. ??Beharri guziak solas berri batera zoazin ear all-D conversation new one-all went \\ "All ears went to a new conversation"}

In (65a), the reference object (the door-lock) cannot be interpreted as including or supporting the figure (the priest). And in (66b), the ears do not end up in a new conversation, but are somehow oriented to it. In this case, the Path component is not overtly realized by the allative postposition but by dative marking of the ground DP. The contrasts in (65-66) suggest that the allative and the dative do not freely alternate: the contexts where the allative suffix is used are topologically richer than those where the dative case suffix is used. In an explicit syntactic representation of the underlying spatial relations, it means that they are featurally more complex. The rich spatial content of the simple suffixes probably also explains why they can not be directly merged with animate DPs, which do not easily yield to a purely spatial conception (see Aristar, 1996). Dative case-suffixes, on the other hand, can. We summarize the contexts of use for the allative and the non-agreeing dative in the following table:

(67)

\begin{tabular}{|l|c|c|}
\hline & Path $_{\text {inclusion }}$ & Path \\
\hline Animate & -ri & -ri \\
\hline Inanimate & -ra & -ri \\
\hline
\end{tabular}

We will provide a syntactic analysis of (67) that associates dative and allative suffixes with different structural configurations. Capitalizing on the idea, elaborated in the nanosyntax program (Starke, 2010), that lexical items can spell out non-terminals, we will argue that the allative suffix lexicalizes adpositional structures that contain both a Path and a Place feature, whereas the latter is lacking in those structural configurations lexicalized by the dative. As we will see in the next section, this will force us to revise some of the received views on the syntactic structure of Basque adpositional phrases.

\section{Lexicalizing the adpositional field}

In the following, we construct an argument for the phrasal Spell Out of adpositional structures that is based on two well known observations. One is the similar topological restrictions that delimit the range of objects the simple spatial suffixes (inessive, allative and ablative) can combine with (section 6.1). The other one is the syntactic asymmetries that arise between the inessive and the other two spatial suffixes in their ability to combine with other functional heads (6.2), a classic problem in Basque adpositional syntax.

\subsection{Topological restrictions in simple postpositions}

We start by noting that the topological restrictions that arise in the case of the allative are also shown by the inessive. Thus, the inessive suffix (68b), exactly as the allative one (68a), cannot be directly merged to an animate DP:

$$
\begin{aligned}
\text { a. *Zu-ra } & \text { b. *Zu-n } \\
\text { you-all } & \text { you-iness } \\
\text { "To you" } & \text { "In you" }
\end{aligned}
$$

Aurnague (2001:103-112) shows that the inessive in Basque imposes relatively specific 
constraints in the relation between the figure and the ground. Roughly, the entity represented by a ground with an inessive suffix is such that it must either include or support the figure. Those conditions are the same that govern the presence of the allative. A simple way of making sense of the parallel restrictions shown by the allative and the inessive in contexts like $(68 \mathrm{a}, \mathrm{b})$, is to say that the allative inherits the restrictions imposed by the inessive. In other words, that the allative lexicalizes both Path and Place features. As shown by an increasing amount of cartographic work, in complex directional postpositions the Path feature seems to select the Place feature (see Koopman, 2000; Kracht, 2002; Svenonius, 2006; Pantcheva, 2009; Caha, 2009 a.o.), a fact which is expected on conceptual grounds (see Jackendoff, 1990):

\begin{tabular}{|c|c|c|}
\hline \multicolumn{3}{|c|}{ PathP } \\
\hline I & 1 & \\
\hline Path & & \\
\hline & I & 1 \\
\hline
\end{tabular}

Some dialectal variants of north-eastern Basque, as the Souletin variety, overtly realize both the allative suffix and the inessive one. In (70), the inessive is not overtly visible, due to the impossibility of $/ \mathrm{nl} /$ sequences in Basque, but is manifest in the presence of the determiner, that cannot otherwise precede the allative:

$$
\begin{aligned}
& \text { Etxe-a }(* n)-l a t \\
& \text { house-D-iness-all }
\end{aligned}
$$

The order of the affixes, with the inessive closer to the stem than the allative, supports the hierarchical structure in (69).

\subsection{Asymmetries in the complement of $P$}

The syntactic structure of the adpositional domain, as schematized in (69), coupled with the idea that the allative lexicalizes both the Path and the Place features can help us understand a long standing puzzle in the domain of adpositional syntax in Basque: the fact that whereas inessives seem to take DP complements (81a), the complements of allatives and ablatives must be bare $(81 \mathrm{~b}, \mathrm{c})$.
a. Etxe-a-n
b. Etxe-(*a)-ra
house-D-all
c. Etxe-(*a)-tik
house-D-iness
house-D-ablative

We saw that both the conceptual structure of Paths, as well as dialectal evidence internal to Basque, point to a syntactic structure in which Path denoting features (allatives and ablatives) dominate Place denoting ones. If this conclusion is correct it is unclear why the addition of a Path feature on top of Place should cause the disappearance of the article. Whatever the relevant relation, it cannot be stated in terms of selection. The Souletin example in (70) suggests the following generalization:

(72) If the Path and the Place features are independently lexicalized, the ground can be a DP

We would like to connect this generalization with the idea that the article that one sees in the 
nominal complements of inessive postpositions is actually external to the Place postposition. First, note that the purported determiner, which in Basque is associated to familiarity and definiteness (see Etxeberria, 2005), is compatible with an overt indefinite article in the context of ground complements, and this with a clear indefinite interpretation:

(73) Liburua mahai bat-e-a-n dago book-the table one-D-iness is "The book is on $\mathrm{a} /$ *the table"

Sequences of indefinite and definite determiners are possible in Basque, with the meaning of "one of the", and clear definite (and distributive) interpretation (74), none of which properties are manifest in the ground case:

(74) Bat-a-k 100 orrialde zituen, beste-a-k 150

one-D-erg 100 page had, other-D-erg 150

"One of the books had 100 pages, the other one 150"

We can add to this the non-referential interpretation of the determiner when it occurs in between an overt nominal locative and the inessive (75a), which should be contrasted with the referential uses of $-a$ when it heads a DP (75b):

a. Etxearen aurre-a-n house-gen front-D-iness

"In front of the house"

b. Etxearen aurre-a house-gen façade-D

"The façade of the house"

Besides the fact that the determiner preceding the inessive presents semantic properties unlike those in normal nominal contexts, it also shows syntactic restrictions which are unlike those found in canonical DPs. Etxeberria (2005) has shown that the determiner $-a$ in Basque selects a number head, which is affixed into the determiner at PF, giving rise to the affix order DNumber. When the number is plural, the complex determiner head has the form $-a k$ in (76):

Liburu-a-k

book-D-Number

"Books/the books"

The ground complements of inessive suffixes, and of spatial suffixes in general, have the intriguing property of not accepting the plural determiner:

$$
\begin{aligned}
& \text { *Liburu-a-k-e-n } \\
& \text { book-D-Num-inessive } \\
& \text { "In the books" }
\end{aligned}
$$

Number in the complement of spatial suffixes in Basque is carried by a special suffix that directly attaches to the nominal stem:

Liburu-eta-n 
book-pl-iness

"In the books"

In fact, plural grounds do not admit determiners either: the distinction between definite and indefinite plurals is realized via allomorphy: the suffix -eta- encodes definiteness and plurality; the suffix $-t a$ - encodes indefiniteness and plurality:

$$
\begin{aligned}
& \text { a. Etxe-eta-n } \\
& \text { house-pl-iness } \\
& \text { "In the houses" }
\end{aligned}
$$

\author{
b. (Hainbat) etxe-ta-n \\ so-many house-pl-iness \\ "In so many houses"
}

The asymmetry between plural and singular determiners remains mysterious under the idea that the inessive postposition takes a complement headed by the determiner $-a$. But if $-a$ is not the canonical determiner one finds in definite DPs in Basque, what is its status in the inessive cases? Since Koopman's seminal paper (2000) on the Dutch adpositional system, we know that the structure of simple PPs must be extended to provide room for various functional projections. The idea behind Koopman's analysis is that in the same way that nouns and verbs project functional structure, lexical adpositions can also be shown to do so. In Den Dikken's elaboration of this idea, both Place and Path adpositions project functional structure which is akin to the one found in nominal and verbal phrases. Concretely, Den Dikken (2010:100) proposes the following parallel functional skeleton for all lexical categories $\mathrm{N}, \mathrm{V}$ and $\mathrm{P}$ :

$$
\begin{aligned}
& \text { a. }\left[{ } _ { \mathrm { CP } } \mathrm { C } ^ { [ \mathrm { FORCE } ] } \left[{ } _ { \mathrm { DxP } } \mathrm { Dx } { } ^ { [ \mathrm { TENSE } ] } \left[\mathrm{AspP}^{\mathrm{Aspp}}{ }^{[\mathrm{EVENT}]}[\mathrm{vp} \mathrm{V} \ldots \text {...]]]] }\right.\right.\right. \\
& \text { b. } \left.\left[{ }_{\mathrm{CP}} \mathrm{C}^{[\mathrm{DEF}]}{ }_{[\mathrm{Dxp}} \mathrm{Dx}^{[\mathrm{PERSON}]}\left[\mathrm{AspP} \mathrm{Asp}^{[\mathrm{NUMBER}]}[\mathrm{NP} \mathrm{N} \ldots . .]\right]\right]\right] \\
& \text { c. } \left.\left[{ }_{\mathrm{CP}} \mathrm{C}^{[\mathrm{SPACE}]}{ }_{\mathrm{DxP}} \mathrm{Dx}{ }^{[\mathrm{SPACE}]}\left[\mathrm{AspP} \mathrm{Asp}^{[\mathrm{SPACE}]}[\mathrm{PP} \mathrm{P} \ldots]\right]\right]\right]
\end{aligned}
$$

In the adpositional field, the C-layer is involved in the extraction of adpositional heads out of the PP (Van Riemsdijk, 1978), DxP is related to deixis, and the aspectual head to the bounded/unbounded status of the location or path. The deictic layer represents how the location or path is oriented vis-à-vis the speaker. Thus, locative adpositions distinguish whether the location is at the speaker' location (here) or away from it (there). In Path adpositions, the head expresses whether the path is oriented towards or away from the speaker. Basque has a deictic contrast in the context of plural determiners. Thus, only in the plural (81b), the determiner $-a$ (unmarked for proximity) contrasts with the proximate determiner $-O$ - (a marked form expressing proximity to the speaker):
a. Etxe-a/-*o
house-D/proximate
"The house"
b. Lagun-a-k/-o-k house-D-pl/proximate-pl
"The houses/the houses here"

In the context of adpositional phrases, the proximate suffix $-O$ - is in complementary distribution with $-e-$, unmarked for proximity, that encodes plurality:
a. Etxe-e-ta-n house-SC-suffix-iness
"In the houses"

b. Etxe-o-ta-n house-proximate-suffix-inessive

"In the houses here"

The absence of a proximate singular determiner alternating with $-a$ suggests that the determiner and the proximate deictic affix do not occupy the same syntactic position. The proximate affix is involved in the deictic location of the noun it is associated to, and it 
syncretically expresses number in the inessive cases. The dependency of the proximate deictic determiner on number suggests it selects a number feature, as argued by Den Dikken:

$$
\text { ...[DeicP }-\mathrm{O}[\mathrm{NumP}-\mathrm{k}[\mathrm{NP} \mathrm{N} \ldots]]]]
$$

Both $-e$ - and $-O-$, on the other hand, may trigger the definite interpretation of the Ground (this is the most natural interpretation in $(82 \mathrm{a}, \mathrm{b}))$. We will conclude that the affixes in question can syncretically realize Definite D in the complement domain of the Place head. This, on the other hand, constitutes further evidence that the determiner $-a$ in the inessive cases is an external functional projection, not related to definiteness.

The separation of the Determiner $-a$ from the functional set associated to the Ground yields the following structure: ${ }^{14}$

$$
\text { .[ -a ...[PlaceP }-\mathrm{n}[\mathrm{DP} \mathrm{D}[\mathrm{DeicP}-\mathrm{O}[\mathrm{NumP}-\mathrm{k}[\mathrm{NP} \mathrm{N} \ldots]]]]
$$

The external status of the determiner $-a$ in the inessive constructions is not surprising. The Basque determiner $-a$ is known to operate at very different syntactic levels. As shown by Artiagoitia (1995), it can encode Tense in clausal nominalizations (see also Etxepare, 2006). Consider the following minimal pair:

a. Patatak ja-te-n joango gara potatoes eat-Nom-iness go we-are

"We will leave eating (the) potatoes"

b. Patatak ja-te-a-n, joango gara potatoes eat-Nom-Det-iness, go-fut we-are

"We will leave when we eat (the) potatoes"

(85a) presents a gerundive clause. It is composed at least by the VP patatak jan "eat potatoes" a nominalizing affix -te normally associated to clausal nominalizations, and the inessive suffix $-n$, which selects an interval within the time boundaries of the eating event (see Demirdache and Uribe-Etxebarria, 2000, 2002, 2004, for an analysis of progressive forms in the context of a topological approach to Tense and aspect relations). Minimally contrasting with (85a) is (85b), which involves the same nominalized base as (85a) but contains a determiner between the nominalizing suffix and the inessive. The determiner picks up a contextually salient temporal event, that specifies the interval denoted by the matrix future temporal morpheme. Interestingly, when the determiner picks up a temporal interval, plural marking is excluded. Consider the following minimal pair, adapted from Etxepare (2006):

(86) Xabier etortzea eta Miren joatea nahi dut/*ditut

Xabier come-nom-D and Miren leave-nom-D want aux(sing)/aux(pl)

"I want Xabier to come and that Mary leaves"

If the D layer had a singular number feature, we would expect conjunction of the nominalized clauses to trigger plural agreement in the auxiliary. Since this is not possible, it must be that $\mathrm{D}$, and the nominalized clause it heads, do not possess number features. The determiner $-a$ in

\footnotetext{
${ }^{14}$ Note that there is no way to state the "external" position of the determiner in simple minded head-final representation, in which the inessive selects the article. See footnote 13 for references on the antisymmetry debate in Basque.
} 
clausal nominalizations is also involved in licensing overt subjects (possible in (85b), but not in (85a). San Martin (2001) and Etxepare (2006), take $-a$ to lexicalize T/C.

The unlikely behaviour of the determiner following the inessive in the light of DP structure in Basque, as well as the restriction on number that assimilates $-a$ to the kind of left-peripheral article occurring in clausal nominalizations, suggests an analysis whereby $-a$ does not belong in the complement of the Place adposition, but is generated outside it, in the extended projection of P. We will follow Koopman (2002) and Den Dikken (2006) in the idea that lexical adpositions project a number of functional projections, akin to other lexical categories such as nouns and verbs. Capitalizing on the well established status of Basque $-a$ as a multifunctional head expressing various notions related to temporal and individual deixis, we will locate $-a$ in the extended functional domain of the Place adposition, as related to Den Dikken's C. If this is correct, the determiner would actually dominate the Place adposition. Let us represent this projection as follows:

$$
\text { [CP/DeicticP -a [PlaceP -n [ NP]]] }
$$

The NP raises to the external functional projection $\mathrm{C} / \mathrm{D}$, yielding (88):

$$
\text { [CP/DeictiP etxe }-\mathrm{a} \text { [PlaceP }-\mathrm{n} \text { etxe]] }
$$

\subsection{Adding Path}

Consider the idea that directional Paths select (88):

$$
\text { [PathP Path }{ }^{0}\left[\mathrm{CP}-\text {-a [PlaceP Place }{ }^{0}\right. \text { [ NP]]] }
$$

The result of moving the NP to the external D projection will be (90):

$$
\text { [PathP Path }{ }^{0} \text { [CP NP-a [PlaceP Place }{ }^{0} \text { [ NP]]] }
$$

Now imagine that the insertion context of the allative suffix is the following:

$$
\begin{aligned}
& \text { all }=>\quad \text { PathP } \\
& \begin{array}{c}
\text { / I } \\
\text { Path PlaceP }
\end{array} \\
& \text { / }
\end{aligned}
$$

The configuration in (90) does not allow the insertion of the allative, since the DP intervenes. A possible way out would be pied-piping the whole DP projection to the Spec of the Path Phrase:

$$
\left[\text { PathP }\left[\text { CP NP -a }\left[\text { PlaceP Place }^{0} \ldots\right] \text { Path }^{0} \ldots\right]\right.
$$

But in this case the syntactic configuration does not license the insertion of the allative, either. The Place feature having been removed from the complement domain of the Path head, (92) does not represent (91). In other words, there is no way to comply with the insertion context of the allative if the DP raises to a functional projection intervening between the Path and the Place heads. The Place head will not have the same problem. Consider the relevant structure: 
If the inessive only lexicalizes the Place feature, the DP cannot intervene in any relevant way.

The proximate and number features do not produce the kind of intervention effect we observed for the determiner $-a$ :
a. Etxe-o-ta-ra house-proximate-suf-all
b. Etxe-e-ta-ra house-pl-suf-all
"To the houses here"
"To the houses"

This is unsurprising if those features are lower than the inessive and raise together with the nominal ground to the Spec of the allative:

$$
\text { [PathP [DP Etxe-e/o-ta] -ra...] }
$$

The lexicalization rule in (91) for the allative addresses an obvious question that arises once we accept that the adpositional domain is hierarchically structured in terms of features encoding different aspects of spatial configurations. If Path features are represented as selecting Place features, we must wonder why the Basque suffixes representing Place and Path are in complementary distribution, in all varieties except Souletin. The idea that in those varieties, the allative lexicalizes something more than Path provides a plausible answer. The ablatives representing sources in Basque show the same animacy restrictions as allatives and inessives, and they impose the same restrictions on the nominal complement as allatives do. If we follow Pantcheva (2009) in the idea that sources dominate Paths, it is reasonable to think that ablatives inherit their semantic restrictions in the same way as allatives do. We will take them to lexicalize the whole adpositional field:

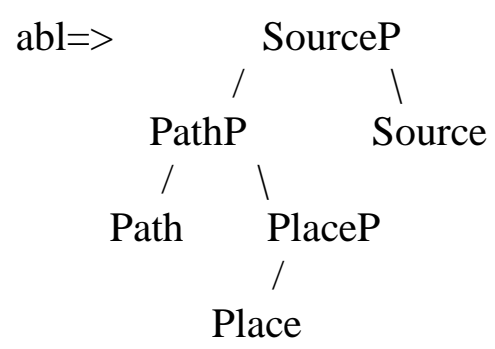

Again, an intervening functional projection hosting the ground DP would destroy the syntactic configuration for lexical insertion.

In other words, only the lowest adpositional head will be able to license a higher functional projection, because only in those cases the adpositional form lexicalizes a single feature, and no intervention effect arises. (97) recapitulates in a schematic way the lexicalization patterns of simple spatial suffixes:

$$
\begin{aligned}
& \text { Inessive }->\{\text { Place }\} \\
& \text { Allative }->\{\text { Path, Place }\} \\
& \text { Ablative }->\{\text { Source, Path, Place }\}
\end{aligned}
$$

\section{Silent Paths and Dative Case}


Silent Path adpositions seem to select fully fledged nominal grounds. Unlike with the allative suffix, the silent Path requires a DP ground, which furthermore surfaces with dative case:
a. Oro itsasoari daude
all sea-D-dat are-loc
"All of them are looking at/facing the sea"
b....BE $\left[\emptyset_{\text {PATH }}\left[\right.\right.$ the sea $\left.\left.{ }_{\text {DAT }}\right] \ldots\right]$

If the previous analysis that accounted for the obligatory bare status of NP grounds with allatives and ablatives was on the right track, it must be that the silent Path does not lexicalize together the Path and the Place features. Since it doesn't, there is no reason why the nominal ground of an adposition should be bare. The issues raised by the structure in (98) are of a different sort. First, there is the question of why the construction in (98) is bound to a limited set of spatial relations ranging from unbounded directional paths to configurations of surface contact between the figure and the ground. Then, if (98a) follows from the fact that the Path adposition is independently lexicalized, there is the question of why the Place feature is not overtly lexicalized by the inessive $-n$. As we will see, the two issues are related.

\subsection{Spatial datives}

There is at least one respect in which dative marked grounds differ from the grounds in inessive phrases. The Ground in the dative cases is clearly a regular DP. There is for instance no available sequence of indefinite and definite determiners in the Ground of invariant postpositions, unlike in the case of inessives (99a). The indefinite determiner bat "one/a" is in complementary distribution with the article $-a$, expressing definiteness and familiarity in this case $(99 b, c)$ :

$$
\begin{aligned}
& \text { a. Etxe bat-e-a-n } \\
& \text { house one-D-iness } \\
& \text { "In a house" }
\end{aligned}
$$
b. *Etxe bat-e-a-ri house one-D-dat "To a house"
c. Etxe bat-i house one-dat "To a house"

Remember that (99a) was possible because the overt article $-a$ is external to the Place adposition, exerting a function which is closer to that of a complementizer:

$$
[\mathrm{CP}-\mathrm{a}[\ldots[\text { PlaceP }-\mathrm{n}[\mathrm{DP} \text { etxe bat }]]
$$

By the same reasoning, the determiner in the dative case cannot be external in this sense. It must belong in the same extended domain that includes the number feature. We conclude that the internal structure of Path related dative grounds lacks the external $\mathrm{C}$ projection:

(101) * [PathP Ø [CP -a [...DP-dat...]]

Note that the inessive did not allow the presence of $-a$ in the DP ground: a syncretic affix $-e$ or the proximate determiner $-o$ - were taken to lexicalize $\mathrm{D}$ in those cases. The simplest way to adress the lack of an overt inessive suffix and the presence of $-a$ in the dative cases, is to say that the inessive is simply absent. This constitutes a problematic move under the premises that the inessive is a lexical adposition that contributes the basic locative function associated to the structure. But consider again the derivation in (88), repeated below: 


$$
\begin{aligned}
& \text { a. [cP -a [PlaceP -n [ NP]]] -> raising of NP to Spec of CP } \\
& \text { b. [cP etxe -a [PlaceP -n etxe]] }
\end{aligned}
$$

The bare ground selected by the Place adposition raises to the Spec of the external C head, apparently stranding the lexical preposition behind. Basque, however, does not have preposition stranding. The status of the inessive, we think, fits better in the overall picture if it, like the external determiner $-a$, is a functional head. We know independently that the inessive in Basque is used to encode aspect, with a meaning akin to its spatial meaning (see 85a). Let us therefore amend our structure in (100) into something like (103):

(103) $[\mathrm{cP} / \mathrm{DP}-\mathrm{a}$ [AspP $-\mathrm{n}[\mathrm{NP}]]]$

The absence of the inessive in the dative cases corresponds therefore to the absence of a (given) lexical instantiation of the aspectual head in the locative domain. ${ }^{15}$

The dative cases must nevertheless possess some locative content different from the ground itself. Take for instance the orientation function of adverbs such as bisean-bis "face-to-face". The relevant spatial relation does not only specify a directional path from the Figure to the Ground, but also a particular way of locating the Figure with respect to the Ground: someone who is face-to-face to a reference term stands in relation to a certain projected space from that reference term. A projected space which is defined on the basis of the inherent directed vertical and horizontal axes of the ground (Jackendoff, 1992:111). This projected region is syntactically represented by means of a feature encoding projected space: the Axial Part head. We will therefore conclude that the relation between the Path head and the nominal ground is mediated by a syntactic head encoding projected space. The Axial Part selects a nominal ground that can project up to $\mathrm{D}$ :

$$
[\text { PathP } \varnothing \ldots[\text { AxP Ax [DP ...NP]] }
$$

From the standpoint of (104), we may wonder what the effect of eliminating the inessive suffix would have in the overall meaning of the spatial structure. Aurnague (2001) provides a detailed examination of the different semantic values that the inessive adopts. They are basically two: inclusion and support. Let us consider the first notion. The addition of an inclusion relation in a Path structure should have as a result the bounded interpretation of the Path. The elimination of the inclusion relation linking the Path to the projected region from the Ground basically means that the Figure does not attain the spatial Goal. This captures immediately all those spatial relations that we described under the concept of oriented paths. Oriented paths, by definition, do not lead the Figure to the Ground. The following invariant postpositions can be seen to fall under the notion of oriented path:

(105) Etxeari buruz/begira/bisean-bis

house-D-dat towards/looking/face-to-face

"Towards the house/looking at the house/facing the house"

In all those cases, the absence of the inessive allows the unbounded interpretation of the directional Path introduced by the invariant postpositions.

\footnotetext{
${ }^{15}$ This entails that the lexicalization rule that targets the Path and the aspectual feature denoted by the inessive lexicalizes together lexical and functional material. For the factual availability of this option, see recently Dekanyi (2009) and her analysis of Hungarian postpositions.
} 
The aspectual contrast associated to the alternation between dative and inessive grounds suggest they both represent different values of a same aspectual category. Whereas the inessive, via an inclusion spatial feature, would force the meaning that the Figure is included within the Ground, the dative would be associated to unbounded aspect. The latter conclusion is supported by the presence of the dative in complements of atelic aspectual verbs, as seen in section 2.3. We thus extend the structure in (104) to include an aspectual head that specifies the bounded or unbounded status of the Path: ${ }^{16}$

$$
\left[\text { PathP } \varnothing \left[\mathrm{AspP}-\mathrm{n} /-\mathrm{ri}\left[\mathrm{AxP}_{\mathrm{Ax}} \mathrm{Ax}^{0}[\mathrm{DP} \ldots \mathrm{NP}]\right]\right.\right.
$$

Let us consider now the second basic semantic value of the inessive suffix, the expression of support. As Aurnague notes (2001:107, footnote 6), not any support configuration is expressed by the inessive. For the inessive to be felicitously used, the Ground must be the only stabilizer of the Figure. Thus, we would use the inessive to describe a set of bookcases fixed to a wall, but not to describe one which is lying on the floor and against the wall. For the latter case, north-eastern Basque employs kontra "against" plus a dative ground. (107a,b) illustrate the difference:

(107) a. Ipini ezazu apalategia paretan put imperative bookcase-D wall-D-on

"Fix the bookcase to the wall"

b. Ipini ezazu apalategia paretari kontra put imperative bookcase-D wall-dat against

"Put the bookcase against the wall"

(107b) shows one of the dative taking invariant postpositions of Basque. Interestingly, kontra only occurs with a dative Ground when the overall meaning of the spatial relation clearly includes location. Purely directional cases are not enough. Consider in this regard the contrast arising in north-eastern varieties between the following two cases:

(108) a. Berlingo harresiaren kontra mintzatu da Berlin-gen wall-gen against talked is

"He/she talked against the Berlin wall (she/he criticized it)"

b. Berlingo harresiari kontra mintzatu da

Berlin-gen wall-D-dat against talked is

"She/he talked as she/he was resting against the Berlin wall"

Support configurations are expressed by those verbs that represent contact, such as the verbs of attachment or union discussed in section 4.5. All those verbs take dative Grounds in northeastern varieties. In all those cases, the supporting entity (the Ground) is not the only stabilizing agent in the relation. Other elements, such as ties and ropes play a crucial role as stabilizers. In those cases, the inessive is excluded.

\footnotetext{
${ }^{16}$ For the sake of concreteness, I take the dative suffix to lexicalize the aspectual head. It could be that the dative is just the spell out of a morphological case directly merged to the DP. Nothing in this paper hinges on that. In the nanosyntax approach, as developed by Caha (2009), cases are independent features heading their own projection, and stacked in a hierarchical order above a nominal phrase.
} 
The hypothetical aspectual basis of the alternation between the dative and the inessive is more difficult to discern in the case of supporting configurations. Although the notion of inclusion extends naturally to the domain of aspectual ontology, the notion of support does not. We think that the complementary distribution of the dative and the inessive suffixes makes sense if the aspectual projection in the locative domain is sensitive to the notion of spatial overlap between the Figure and (a projected region from) the Ground. In the inclusion relation, the Figure is exhaustively included in the region projected from the Ground. In the support relation, the inessive only surfaces if the Figure is located in such a way that its contact area is fully within the space projected from the Ground. In this case, the inclusion relation is relativized to those areas that stand in a contact configuration. Jackendoff (1990) proposes that verbs of attachment must be represented in the lexicon as locative configurations specified by a diacritic expressing contact (see (28)). We claim that the relevant aspectual relations are computed relative to the spatial areas of the Figure that are specified as being in contact with the Ground.

\subsection{Aspectual datives}

Our analysis of the alternation between the inessive and the dative suffixes extends in a straightforward fashion to the domain of aspectual datives. Since the Dative suffix lexicalizes unbounded aspect, it is only natural to find it in the complement of atelic aspectual verbs like the progressive ari:
Eta horren ahultzeari
ari zirezte
and that-gen weaken-Nom-D-dat prog are
"And you are weakening that"

In Etxepare (to appear) I argue that the syntactic structure of aspectual complements includes a silent Path adposition that selects a nominalized clause. Under the analysis proposed here, the structure of the aspectual cases must be as in (110), with the nominalized clause in the Spec of the unbounded aspectual head:

$$
\emptyset_{\text {PATH }}\left[\text { AspP } \left[\text { Nominalized Clause } . . . V \ldots . . . \text { Asp }_{\text {DAT } \ldots .]}\right.\right.
$$

A different case is that of Basque directional postpositions gora "up" and behera "down", which have the property of enforcing the atelic reading of the predicates they merge with. In other words, unlike in English, they cannot be used to point to a location in the path:
a. *Etxea mendiari behera dago house-det mountain-dat down is
"The house is down the mountain"
b. Mendiari behera joan gara mountain-dat down go aux[1plA]
"We went down the mountain"

This property goes together with another one: unlike the spatial datives examined in the preceding section, the DP-ground of directional postpositions can show up as (i) a bare noun (112a), (ii) an absolutive DP (112b), or (iii) a dative DP (112c). Compare in this regard (112ac), illustrating the various structural options available to grounds of directional postpositions, with the rigid (113), corresponding to the unbounded locative ones: 
(112)
a. Mendi behera
mountain-down
"Down the mountain"
c. Mendi-a-ri behera
mountain-D-dat down
"Down the mountain

(113) Paret*(ari) kontra/buruz/bisean-bis

wall D-dat against/towards/face-to-face

"Against/towards/facing the wall" b. Mendi-a behera mountain-D down

"Down the mountain"

The different structural options represented in (112) show that the inner aspectual projection associated to location is not necessary for the unbounded interpretation of the whole postpositional phrase. (112a,b) indicate that the aspectual head is lacking. (112a) presumably represents a case where a bare ground incorporates into the Axial head. (112b) a case where a fully fledged DP ground raises to the specifier of the Axial Phrase:

(114) a. [PathP Ø [AxP N+Ax...]]

b. [PathP $\varnothing[$ AxP DP Ax...]

(112c) represents the case where the DP raises to the specifier of the aspectual phrase:

[PathP $\varnothing[$ AspP DP-ri ...]]

We will claim therefore that the aspectual contribution of gora and behera happens in a higher layer of structure, the one projected by the invariant Path postposition. The conclusion is reminiscent of Den Dikken's analysis of the accusative/dative alternation in the domain of spatial adpositions in Germanic. Under this analysis, the dative case is licensed in the extended functional domain of a Place adposition, whereas accusative case is licensed in the extended domain of a directional postposition (Den Dikken, 2010:114). In the spirit of Den Dikken's proposal, the absolutive nominal grounds in $(112 \mathrm{a}, \mathrm{b})$ are licensed in the domain of the invariant directional postposition: ${ }^{17}$

$$
\text { [AspP DP-absolutive Asp [PathP behera/gora [AxP Ax ...]] }
$$

We must wonder now why the aspectual reading that arises in the above cases is of the unbounded type. There is nothing per se in the projection of an aspectual head that forces an unbounded reading, witness the aspectual alternation between the inessive and the dative in the locative domain. We think that a comparison of the above cases with the adverbial cases can shed some light in what is going on. Remember that the adverbial cases behave for all purposes as regular allative adpositional phrases with an underlying Axial Part Noun. This axial noun can constitute an antecedent for anaphora, and provide the basis for nominal compounding. In our terms, that means that the underlying structure of the adverbial cases is the following:

\section{(117) [PathP Path [PlaceP Place [AxP locational noun ]]]]}

\footnotetext{
${ }^{17}$ For the dative DP cases, we will assume the whole aspectual phrase pied-pipes to the Spec of the Path aspectual Phrase.
} 
Along the syntactic derivation, the nominal behe "downside" raises to a syntactic position that is beyond the Path head. The syntactic configuration is one that licenses the lexicalization of the Path and Place heads as the allative -ra:

\section{(118) [ locational noun ...[PathP Path [PlaceP Place behe]]}

One question that immediately arises is how the axial noun gets its case. Since there is no intervening aspectual projection in the Place domain, there is no functional structure to license case there. The case of the axial part must therefore be licensed in the domain of the directional adposition. Let us say that the directional adposition, as in the gora and behera cases, projects an aspectual head that licenses the axial noun:

\section{[AspP locational noun Asp [PathP Path [PlaceP Place loeational nom]]}

The adverbial structure in (119) is not that different from the one we proposed for the invariant postpositional phrases with absolutive grounds, repeated below:

$$
\text { [AspP DP Asp [PathP behera/gora [AxP Ax ...]] }
$$

There is one important regard however in which both structures differ: (119), but not (120) possesses a Place feature, associated to the expression of bounded aspect. The simple allative, furthermore, is a bound form that occurs on the locational noun Let us say that the simple allative adposition adjoins to the aspectual head, and that aspect calculus takes place there. In that case we will have a feature complex composed by a directional feature and a bounded locative one, expressing an inclusion relation, in the aspectual head. The presence of the bounded Place feature triggers the bound interpretation of the adverbial cases.

$$
\text { [AspP behe Asp }+r a_{\{\text {Path, bounded Place }\} . . .]}
$$

In the case of invariant postpositions, the underlying structure does not include a bounded aspect head (see (120). In this case, adjunction of the Path head to the aspect head does not yield the type of feature complex resulting from the adjunction of the allative Path head:

$$
\text { [AspP DP Asp+behera/gora }{ }_{\text {Path }}[\text { PathP behera/gora }[\mathrm{AxP} \text { Ax ...]] }
$$

In the absence of the Place/aspect feature, the Path will interpreted as unbounded. The unbounded interpretation of the Path, on the other hand, forces the atelic interpretation of the predicate it combines with.

\subsection{Animacy}

As shown in table (65), simple suffixes such as the inessive and the allative cannot be directly combined with animate DPs. In our analysis, this means that animate grounds in Basque do not constitute appropriate landmarks to sustain inclusion or support relations. Dative goals therefore project an aspectual phrase of the unbounded type in the locative domain:
a. Jon-i
b. [AspP Jon-i Asp [AxP Ax ...]]
Jon-dat
"to Jon" 


\subsection{A note on Case, Aspect and Number}

Our examination of the Place adpositional domain in Basque yields the maximal structure in (124):

$$
\left[\mathrm{C} / \mathrm{T}-a\left[\mathrm{AspP}-n /-r i\left[\mathrm{AxP}_{\mathrm{Ax}}{ }^{0}\left[\mathrm{DP}^{0} \mathrm{D}^{0}\left[\text { DeicticP } \text { Deixis }^{0}{ }_{\mathrm{NumP}} \mathrm{Num}^{0} \mathrm{NP}\right]\right]\right.\right.\right.
$$

However, not all conceivable structural instantiations of the syntactic elements in (124) are possible. One important restriction concerns the relation between the Place-external article $-a$ and the category of the ground. Bare nominal grounds, as well as indefinite ones headed by bat "one", obligatorily raise to $\mathrm{C} / \mathrm{T}$ :
a. Etxe-a-n
b. Etxe bat-e-a-n house-D-iness house one-D-iness
"In the house/at home"
"In a house"

Raising to unbounded Asp is impossible for those elements:
a. *Etxe-n
b. *Etxe bat-e- $\mathrm{n}$
c. $*[\operatorname{AspP} \mathrm{NP}-n /-r i \ldots]$ house-iness house one-iness

The crucial element in the availability of raising to unbounded aspect seems to be (overt) number. We note first that plural indefinite grounds do raise to aspect:
a. Hainbat etxetan
b. [AspP hainbat etxeta $-n \ldots]$
so-many houses
« In so many houses »

Unlike the singular indefinite bat "one", the plural indefinite determiner batzu « some » forces raising to unbounded aspect:
a. Etxe batzutan
b. [AspP etxe batzuta $-n \ldots]$ house some-iness
"In some houses"

On the basis of this, we can state the restriction as follows:

(129) If the complement of AxP includes Number, then the Ground raises to unbounded AspP

The connection between aspect and number is well established in the domain of case and agreement (see recently Svenonius, 2002; Pesetsky and Torrego, 2004, for two different views). For Basque, Etxepare (2006, 2009) shows, in the context of Long Distance Agreement in Basque, that that number features must occupy a position lower than person features. This position, he claims, is an aspectual head within the (small) VP.

The generalization in (129) must be supplemented with the following one:

(130) If the complement of $\mathrm{AxP}$ raises to $\mathrm{AspP}, \mathrm{T} / \mathrm{C}$ is not projected 
In other words, Place-external $-a$ is projected only when the Ground is such that it cannot be licensed in AspP. Combining (128) and (129) we reach the following condition on the economy of representations (see Boskovic, 1995):

(131) Project as much structure as you need for Case licensing

\section{References}

\section{Literary Corpus}

Etcheberry, J.B. (1966) Frantziako Erregina. Bayonne:Imprimerie Cordeliers.

Etcheberry, J.B. (1969) Obrak Mintzo. Bayonne:Imprimerie Cordeliers.

Etcheberry, J.B. (1978) Han-Hemenka. Bayonne:Imprimerie Cordeliers.

Etcheberry, J.B. (1980) Berriz Ere Beretarik. Bayonne:Imprimerie Cordeliers.

Etcheberry, J.B. (1981) Hazparneko misionestak. Bayonne:Imprimerie Cordeliers.

Larzabal, Piarres [1991-1998] Lan Guztiak [Complete Works]. Edited by Piarres Xarriton. VIII volumes. Donostia:Elkar.

Pochelu, Leon [Garralda ezizenez] (2008) [1947-1951] Jakitatez jakitate. Erroteta argitaletxea.

Sallaberry, Etienne (1978) Ene sinestea. Itxaropena: Zarautz.

2. Database Basyque: http://ixa2.si.ehu.es/atlas2/index.php?lang=eu

\section{Theoretical bibliography}

Albizu, Pablo (2001) "Datibo sintagmen egitura sintaktikoaren inguruan:eztabaidarako oinarrizko zenbait datu" In Beatriz Fernandez and Pablo Albizu (eds) Kasu eta Komunztaduraren Gainean-On Case and Agreement. Bilbao:University of the Basque Country. 49-70.

Arteatx, I., X. Artiagoitia and A. Elordieta (eds) Antisimetriaren hipotesia vs. Buru parametroa: euskararen oinarrizko hitz hurrenkera ezbaian. Bilbao: University of the Basque Country.

Artiagoitia, X. (1995) Verbal projections in Basque and Minimal Structure. ASJU 28-2 :341504.

Aurnague, M. (1996) "Les noms de localisation interne: tentative de caracterisation sémantique à partir des données du basque et du français" Cahiers de lexicologie, 69:159-192.

(2001) Entités et relations dans les descriptions spatiales: l'espace et son expression en basque et en français. Mémoire d'habilitation. Université de Toulouse-Le Mirail.

Arotçarena, A. (1951) Grammaire Basque. Dialectes Navarro-Labourdins. Librairie Le Porche. Bayonne. 
Broadwell, G.A. (1996) "Directionals as complex predicates in Choctaw" In M. Butt and T. Holloway (eds) Proceedings of the LFG98 Conference. Stanford: CSLI Publications.

Boskovic, Z. (1995) The syntax of non-finite complementation. MIT Press.

Caha, P. (2009) The nanosyntax of case. Doctoral dissertation, University of Tromso.

Cinque, G. and L. Rizzi (2010) Mapping Spatial PPs. The Cartography of Syntactic Structures. Volume 6. Oxford Studies in Comparative Syntax. Oxford University Press.

Demirdache, H. And M. Uribe-Etxebarria (2000)

Den Dikken, M. (2010) "On the functional structure of locative and directional PPs" In Cinque, G. and L. Rizzi (eds) 74-126.

Etxeberria, U. (2005) Quantification and Domain Restriction in Basque. Doctoral dissertation. University of the Basque Country.

Etxepare, Ricardo (2003) "Valency and Argument Structure in the Basque Verb" In Jose Ignacio Hualde and Jon Ortiz de Urbina (eds) A Grammar of Basque. Mouton Grammar Library 26. Berlin:Mouton. 363-425.

Etxepare, R. (2006) "Number Long Distance Agreement in (sub-standard) Basque" ASJU 401/2: 303-350.

Etxepare, Ricardo and Bernat Oihartzabal (in press) "Hautazko datibo komunztadura ifarekialdeko euskalkietan" Lapurdum XIII.

Etxepare, R. (to appear) "Contact and Change in a restrictive theory of parameters" In C. Picallo and J.M. Brucart (eds) Linguistic Variation and Minimalism. Oxford:Oxford University Press.

Etxepare, Ricardo (in progress) Optional Agreement Phenomena in Basque. Habilitation Thesis. IKER, CNRS.

Etxepare, Ricardo (in progress) "Adpositional Structures in Basque" Ms. IKER.

Eguzkitza, A. (1998) "Postposizioak euskal gramatikan” In I. Turrez, A. Arejita and C. Isasi (eds) Studia Philologica in Honorem Alfonso Irigoien. Bilbao: University of Deusto. 83-88.

Fernandez, Beatriz (1997) Egiturazko Kasuaren Erkaketa Euskaraz. PhD dissertation, University of the Basque Country.

Fernandez, Beatriz eta Jon Ortiz de Urbina (2008) Datiboa hiztegian. Bilbo: Euskal Herriko Unibertsitatea.

Hualde, J. I. (2002) "Regarding basque postpositions and related matters" In X. Artiagoitia, P. Goenaga and J.A. Lakarra (eds) Erramu Boneta. Festschrift for Rudolf P.G. De Rijk. ASJU Supplements 44. Bilbao:University of the Basque Country. 325-340. 
Hualde, J.I. and J. Ortiz de Urbina (2003) A Grammar of Basque. Berlin:Mouton.

Haddican, William (2001) "Basque Functional Heads" Linguistics in the Big Apple. CUNY/NYU Working Papers in Linguistics.

Haddican, William (2004) "Sentence Polarity and Word Order in Basque" The Linguistic Review 21-2: 81-124.

Jackendoff, Ray (1983) Semantics and Cognition. Cambridge:MIT Press. (1990) Semantic Structures. Cambridge: MIT Press.

and B. Landau (1992) «Spatial language and spatial cognition» In R. Jackendoff, Languages of the Mind. Essays on mental representation. MIT Press. 99-124. (1996)

Kayne, R. (2010) « The indefinite determiner one" Paper presented in Paris.

Koopman, H. (2000) "Prepositions, postpositions, circumpositions and particles" In H. Koopman (ed) The Syntax of Specifiers and Heads. London:Routledge. 204-260.

Kracht, M. (2002) “On the semantics of locatives” Linguistics and Philosophy 25:157-232.

Lafitte, Pierre (1944) Grammaire Basque. Reprint. Baiona:Elkar [1979]

Pantcheva, R. (2008) “The Place of PLACE in Persian” In A. Asbury, J. Dotlacil, B. Gehrke and R. Nouwen (eds) Syntax and Semantics of Spatial P. Amsterdam: John Benjamins. 305330 .

Pasicki, A. (1998) "Meanings of the dative case in Old English" In W.Van Langendoeck and W. Van Belle (eds) The Dative. Volume 2: Theoretical and Contrastive Studies. John Benjamins. 113-142.

Rebuschi, G. (1999) "Le complexe verbal basque: un regard universaliste" Lapurdum

Rezac, M. (2006) Basque Morphosyntax. Ms. University of Nantes/CNRS.

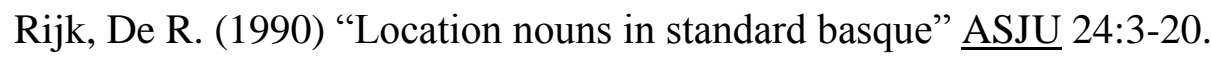

San Martin, I. (2002) On subordination and the distribution of PRO. Doctoral dissertation. University of Maryland.

Svenonius, P. (2010) “Spatial P in English” In G. Cinque and L. Rizzi (eds), 127-160.

Starke, M. (2010) "One more go at the trigger problem: nanosyntax and post-syntactic filtering” Paper presented at the workshop Linguistic Variation in the Minimalist Framework. Barcelona. 
Tortora, C. (2009) "Aspect inside PLACE PPs" In A. Asbury, J. Dotlacil, B. Gehrke and R. Nouwen (eds) Syntax and Semantics of Spatial P. Amsterdam: John Benjamins.

Uriagereka, J. (2008) Syntactic anchors. Cambridge: Cambridge University Press.

Zwarts, Joost (2005) "Prepositional Aspect and the Algebra of Paths" Linguistics and Philosophy 28: 739-779. 